\title{
Evolution of Soil Biochemical Parameters in Rainfed Crops: Effect of Organic and Mineral Fertilization
}

\author{
Marta M. Moreno, ${ }^{1}$ Carmen Moreno, ${ }^{1}$ Carlos Lacasta, ${ }^{2}$ and Ramón Meco ${ }^{3}$ \\ ${ }^{1}$ E. Ingenieros Agrónomos, Universidad de Castilla-La Mancha (UCLM), Ronda de Calatrava 7, 13071 Ciudad Real, Spain \\ ${ }^{2}$ CSIC, Centro de Ciencias Medioambientales, Finca Experimental "La Higueruela", Santa Olalla, 45530 Toledo, Spain \\ ${ }^{3}$ Servicio de Investigación Agraria, Consejería de Agricultura y Medio Ambiente de la Junta de Comunidades de Castilla-La Mancha, \\ Pintor Matías Moreno 4, 45071 Toledo, Spain \\ Correspondence should be addressed to Marta M. Moreno, martamaria.moreno@uclm.es
}

Received 4 December 2011; Accepted 10 April 2012

Academic Editor: Rosario García Moreno

Copyright ( $) 2012$ Marta M. Moreno et al. This is an open access article distributed under the Creative Commons Attribution License, which permits unrestricted use, distribution, and reproduction in any medium, provided the original work is properly cited.

\begin{abstract}
In organic farming, crop fertilization is largely based on the decomposition of organic matter and biological fixation of nutrients. It is therefore necessary to develop studies conducted to know and understand the soil biological processes for the natural nutrient supplies. The effect of three fertilizer managements (chemical with synthetic fertilizers, organic with $2500 \mathrm{~kg}$ compost ha ${ }^{-1}$, and no fertilizer) in a rainfed crop rotation (durum wheat-fallow-barley-vetch as green manure) on different soil biochemical parameters in semi-arid conditions was investigated. Soil organic matter, microbial biomass carbon, organic matter mineralization, $\mathrm{CO}_{2}$ production-to-ATP ratio, and $\mathrm{NO}_{3}-\mathrm{N}$ content were analysed. Fertilization was only applied to cereals. The results showed the scarce effect of the organic fertilization on soil quality, which resulted more dependent on weather conditions. Only soil organic

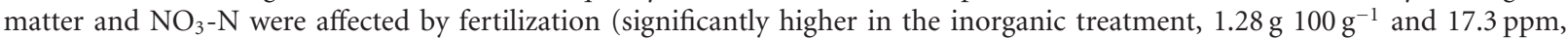
resp.). Soil organic matter was maintained throughout the study period by the inclusion of a legume in the cropping system and the burying of crop residues. In fallow, soil microbial biomass carbon increased considerably $\left(816 \mathrm{ng} \mathrm{g^{-1 }}\right)$, and $\mathrm{NO}_{3}-\mathrm{N}$ at the end of this period was around $35 \mathrm{ppm}$, equivalent to $100 \mathrm{~kg} \mathrm{~N} \mathrm{ha}^{-1}$.
\end{abstract}

\section{Introduction}

Conventional farming has been important for improving food to meet human demands but has been largely dependent on intensive inputs of synthetic fertilizers and pesticides $[1,2]$, both from an economic and energetic point of view. In recent years, the relationship between agriculture and the environment has changed, and concerns regarding the sustainability of agricultural production systems have come to the fore [3]. In this context, organic or ecological farming, focused on the environment and public health, is increasing worldwide [4]. Organic farming avoids the application of synthetic biocides and fertilizers $[5,6]$, promotes the use of renewable resources to prevent pollution [7], may reduce some negative effects attributed to conventional farming, and may have potential benefits in enhancing soil quality [2]. Thus, plant production in organic farming mainly depends on nutrient release as a function of the mineralization processes in soils. Therefore, to get an active soil microflora and an important amount of available nutrients is crucial in these productive systems, being the goal "fertilizing the soil rather than the plant" a priority among organic farmers to assure sufficient nutrient mineralization [8].

The incorporation of organic residues to soils causes a revival of biological and biochemical properties, stimulating microbial growth and metabolic activity as a result of the contributions of new labile carbon sources will serve as a substrate for soil microorganisms. This process is accompanied by an increase of the respiratory rate, releasing $\mathrm{CO}_{2}$ as a reflect of the catabolic processes carried out from the organic supplies [9].

Soil quality is considered as "the capacity of a specific kind of soil to function, within natural or managed ecosystem boundaries, to sustain plant and animal productivity, 


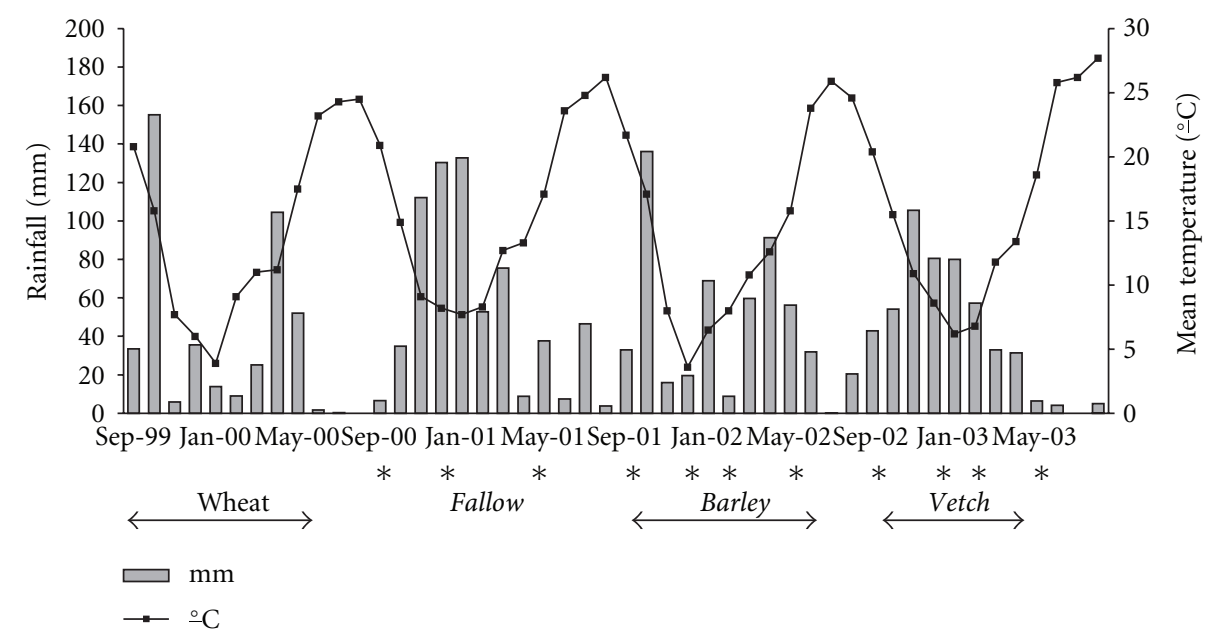

Figure 1: Distribution of rainfall and mean temperature during the field experiment. Crop rotation in the experimental parcels is shown (1999/2000-2002/2003). In italic the crop sequences considered in this study (2000/2001-2002/2003). * Dates of soil sampling.

maintain or enhance water and air quality, and support human health and habitation" [10]. Soil quality is responsible for determining soil ecological functions, such as decomposition and formation of soil organic matter [11], and determines the sustainability and productivity of agroecosystems [12]. Apart from the inherent soil quality, the dynamic soil quality changes in response to human use and management $[8,13]$.

Both the quantity and quality of labile soil organic matter (SOM) play a key role in the functioning and sustainability of agricultural systems, due to its significant impact on the physical, chemical, and biological soil properties [14, 15]. Quantity provides information about the amount of labile $\mathrm{C}$ substrate available to support microbial activity, while quality is related to SOM dynamics and nutrient (C or $\mathrm{N}$ ) supply [14]. SOM is often used as an indicator of soil quality, it generally requires long periods (5-10 years) to detect changes as a result of possible alterations. In contrast, changes in soil microbial biomass carbon (SMBC) and nitrogen (SMBN) and in microbial functions rapidly reflect the impacts of the agricultural management and may change within shorter periods of time, before any changes in chemical or physical parameters are noticed [8, 16]. SMBC provides information on the dimensions of the biomass but not about their metabolic activity, being the soil respiration $\left(\mathrm{CO}_{2}\right.$ production $)$ a measurement of this activity. In general, SMBC increases with increasing total organic carbon content, although this relationship may be affected by macroclimate, soil moisture, soil temperature regimes, and crop rotation [12].

After water, nitrogen is the most limiting factor for crop growth. For this reason, in the $1950-1990$ period, the use of chemical nitrogen fertilizers increased about 10 times, leading to an important increase in cereal yields. However, the application of these fertilizers and other industrial and anthropogenic activities have altered the basic conditions of the natural nitrogen cycle and contributed to nitrate contamination of terrestrial and aquatic ecosystems with great risk to human health [17].
The aim of the present study was to assess the effect of different fertilization managements (organic, chemical, and no fertilization) applied to cereal crops in a rainfed crop rotation (durum wheat-fallow-barley-vetch as green manure) on soil microbiological properties, organic matter, and nitrate content in a semiarid environment over a 3-year period.

\section{Material and Methods}

2.1. Site Description and Experimental Design. Field experiments began in the season 1996/97 at La Higueruela Experimental Farm $\left(4^{\circ} 26^{\prime} \mathrm{W}, 40^{\circ} 04^{\prime} \mathrm{N}\right.$, altitude $\left.450 \mathrm{~m}\right)$, property of the Spanish National Research Council, Santa Olalla, Toledo, in the semiarid region of Castilla-La Mancha (central Spain).

Experiments were based on a typical 4-year crop rotation for semiarid environments: durum wheat (Triticum durum L.)-fallow-barley (Hordeum vulgare L.)-vetch (Vicia sativa L.) as green manure. In this study, the data corresponding to the period 2000/01 to 2002/03 were included (fallow-barleyvetch as green manure) (Figure 1), once finished a complete crop rotation, in order to avoid the possible interferences resulted from the previous uses of the soils.

The climate of the study region is semiarid Mediterranean, with a four-month drought period in summer coinciding with the highest temperatures. From 1975 to 1998, the average annual rainfall and temperature were $445 \mathrm{~mm}$ and $14.4^{\circ} \mathrm{C}$, respectively.

The soil at the experimental site is classified as a Luvisol [18], with very differentiated horizons: A horizon $(0-20 \mathrm{~cm}$, sandy-loam); B horizon (20-60 cm, clay accumulation); C horizon $(60-90 \mathrm{~cm}$, calcium carbonate accumulation); $\mathrm{R}$ horizon $(>90 \mathrm{~cm})$. The main physical and chemical properties of the experiment parcel soils $(0-20 \mathrm{~cm})$ at the beginning of the study (year 2000) are presented in Table 1 , summarized in a sandy-loam texture, a neutral $\mathrm{pH}$, low organic matter and calcium levels, normal magnesium and potassium contents, and a high phosphorus level. 
Trials were designed as randomised complete blocks with three managements of fertilization (chemical, organic, and no fertilization) and four replications. Elemental plots had a size of $100 \mathrm{~m}^{2}(20 \times 5 \mathrm{~m})$. Fertilization was only applied to the cereal crops, as follows-(i) chemical (inorganic) fertilization: a total of 72-45-45 N- $\mathrm{P}_{2} \mathrm{O}_{5}-\mathrm{K}_{2} \mathrm{O} \mathrm{kg} \mathrm{ha}{ }^{-1}$, distributed at sowing in a complex form $\left(300 \mathrm{~kg} \mathrm{ha}^{-1}\right.$ of the 8-15-15 complex) and as a top-dressing at the tillering stage (Duramon 26, 13\% ammoniacal N, 11\% urea N, $200 \mathrm{~kg} \mathrm{ha}^{-1}$ ) (estimated from the average crop extractions and the yield crops in this area); (ii) organic fertilization: $2500 \mathrm{~kg} \mathrm{ha}^{-1}$ of compost applied at sowing, allowed for organic farming use, with the following compounds expressed as $\mathrm{kg} \mathrm{ha}^{-1}$ : organic matter, 1528; total nitrogen, $70 ; \mathrm{P}_{2} \mathrm{O}_{5}, 28 ; \mathrm{K}_{2} \mathrm{O}, 111$; magnesium, 12 ; (iii) no fertilization treatment as control.

2.2. Plant Material and Culture Conditions. In the experiments, the crop varieties used were Hispanic for barley, Oscar for durum wheat, and Senda for vetch. All the crops were sown in November with a conventional sower (row distance $15 \mathrm{~cm})$. The amounts of seeds used were $140 \mathrm{~kg} \mathrm{ha}^{-1}$ for cereals and $100 \mathrm{~kg} \mathrm{ha}^{-1}$ for vetch. The cultivation practices followed were similar to those employed by local growers, adapted to the type of soil and weed incidence, and so forth. Tillage consisted of two or three cultivator operations prior the crop sowings. In cereals, once the crops were combineharvested after reaching physiological maturity in June-July, straw was uniformly incorporated to the same plots where it was produced with a disc harrow. The vetch was also incorporated into the soil with a disc harrow at flowering state (end of April-beginning of May) to be used as green manure. No weed control was practiced in any plot.

In the control treatment, the fertilization for the entire crop sequence only consisted in the $\mathrm{N}$ provided by the vetch crop and the cereal straw.

2.3. Soil Determinations. Soil samples $20 \mathrm{~cm}$ depth were taken in September and December 2000, May, September, and December 2001, February, May, September, and December 2002, and February and May 2003 (Figure 1), coinciding with the end of the meteorological seasons in Mediterranean climates.

In each sample, soil microbiological parameters, organic matter (Walkley-Black), and nitrate $\left(\mathrm{NO}_{3}-\mathrm{N}\right)[19]$ contents were quantified. The soil microbiological parameters analysed, measured according to the methodology proposed by Maire et al. [20], were the following.

(i) SMBC: it expresses the total amount of microbial in soil, mainly bacteria and fungi, measured as the ATP (adenosine triphosphate) content. This parameter could not be measured in October 2001.

(ii) SOM mineralization (SOMM): this quantity is the sum of $\mathrm{CO}_{2}$ production during the 15 days of incubation, expressed on an organic matter basis.

(iii) $\mathrm{CO}_{2}$ production-to-ATP ratio, or specific activity of the microbial biomass. This ratio is similar to
TABLe 1: Initial soil physical and chemical characteristics in the experimental parcel (year 2000).

\begin{tabular}{lc}
\hline Soil parameter & \\
\hline Sand $(2-0.05 \mathrm{~mm})\left(\mathrm{g} 100 \mathrm{~g}^{-1}\right)$ & 68.1 \\
Silt $(0.05-0.002 \mathrm{~mm})\left({\left.\mathrm{g} 100 \mathrm{~g}^{-1}\right)} \mathrm{14.8}\right.$ \\
Clay $(<0.002 \mathrm{~mm})\left(\mathrm{g} 100 \mathrm{~g}^{-1}\right)$ & 17.1 \\
$\mathrm{pH}(1: 2.5$ soil : water $)$ & 6.6 \\
Organic matter (Walkley-Black) $\left({\left.\mathrm{g} 100 \mathrm{~g}^{-1}\right)}^{\mathrm{C} / \mathrm{N}}\right.$ & 1.29 \\
Phosphorus (Olsen) $\left(\mathrm{mg} \mathrm{kg}^{-1}\right)$ & 9.18 \\
Potassium (ammonium acetate extract) $\left(\mathrm{mg} \mathrm{kg}^{-1}\right)$ & 186 \\
Calcium (ammonium acetate extract) $\left(\mathrm{mg} \mathrm{kg}^{-1}\right)$ & 168 \\
Magnesium (ammonium acetate extract $)\left(\mathrm{mg} \mathrm{kg}^{-1}\right)$ & 1381 \\
\hline
\end{tabular}

the more generally used metabolic quotient $\left(\mathrm{qCO}_{2}\right)$, which has been repeatedly used as a stress indicator [21], is related to the disponibility of nutrients, especially organic carbon, and it is often used as an indicator for assessing the influence of the environment conditions on soil microbial communities [22].

2.4. Biomass Measurement. Aboveground biomass was controlled for the entire study, including crop plants and weeds. For this purpose, two samples per elemental plot consisting on three adjacent rows $0.5 \mathrm{~m}$ long (equivalent to $0.23 \mathrm{~m}^{2}$ ) were taken at harvest and dried in a forced air oven at $60^{\circ} \mathrm{C}$ until constant weight. Each season, total biomass incorporated into the soil was calculated from the buried biomass of the previous crop (cereal straw, forage legumes, and root biomass, estimated in $20 \%$ of the total aboveground biomass according to unpublished data from the research group). In the organic treatment, the compost supply was also considered.

2.5. Statistical Analysis. Data were analysed by a two-way analysis of variance (ANOVA) with fertilization treatment and sampling date as main factors. The significance of the corresponding interaction between both factors was studied, and a Duncan's multiple-range test $(P<0.05)$ was applied to the significant results in each case. The statistical analysis was performed with the statistical package InfoStat 2007, professional version.

\section{Results}

3.1. Climate. The monthly rainfall and mean temperature during the period 1999/2000-2002/2003 are shown in Figure 1. The average seasonal (1 September-31 August) rainfall was $532.2 \mathrm{~mm}$, irregularly distributed intra-annually in timing and amount. Rainfall was similar in all autumns (average $184 \mathrm{~mm}$ ), but however it varied considerably in the other seasons; thus, rainfall in summer ranged from $2.0 \mathrm{~mm}$ in $2000 / 2001$ to $57.7 \mathrm{~mm}$ in $2001 / 2002$, in winter from $58 \mathrm{~mm}$ in $1999 / 2000$ to $315.9 \mathrm{~mm}$ in $2000 / 2001$, and in spring from $70.5 \mathrm{~mm}$ in $2002 / 2003$ to $207.1 \mathrm{~mm}$ in 
2001/2002. The average annual temperature was $15.2^{\circ} \mathrm{C}$ (winter, $6.9^{\circ} \mathrm{C}$; spring, $13.8^{\circ} \mathrm{C}$; summer, $24.2^{\circ} \mathrm{C}$; autumn, $\left.15.2^{\circ} \mathrm{C}\right)$.

3.2. Crop Biomass and Organic Matter Supplies. Aboveground vegetal biomass in the different crops was significantly affected by the fertilization treatment over the study period (Table 2), being in all cases higher in the chemical treatment. In relation to the total inputs of organic matter to the soil (Table 3), no differences among treatments were found; however, it should be noticed that the compost dose was also considered as an input in the organic treatment, being lower the amount of vegetal biomass incorporated into the soil in this treatment, especially from the barley crop.

3.3. Soil Biological Parameters. The ANOVA for the soil parameters analysed is summarized in Table 4. In general, no interactions between the fertilization treatment and the sampling date were significant in any case, which allowed to study the simple effects of each factor. Differences in all soil variables analysed were observed among the sampling dates, mainly as result of variation in weather conditions; however, the effect of the fertilization treatment was only significant on the $\mathrm{SOM}$ and $\mathrm{NO}_{3}-\mathrm{N}$ variables.

The soil results obtained throughout the whole experiment are presented in Table 5. Averaged across sampling dates, SOM was significantly higher with chemical fertiliza-

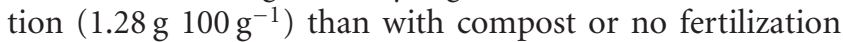

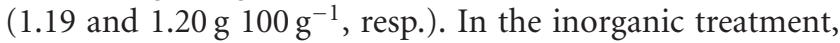
the highest SOM corresponded to the barley crop, when fertilization took place.

SOMM ranged from $358 \mu \mathrm{g} \mathrm{OMg} \mathrm{g}^{-1} 15 \mathrm{~d}^{-1}$ in the inorganic treatment to $337 \mu \mathrm{g} \mathrm{OMg}^{-1} 15 \mathrm{~d}^{-1}$ in the control (Table 5), although no differences among treatments were found. Throughout the study period, it is remarkable the high average SOMM reached in Sept 2000 (721 $\left.\mu \mathrm{g} \mathrm{OM} \mathrm{g}^{-1} 15 \mathrm{~d}^{-1}\right)$. During the fallow period, SOMM was high and practically constant (Dec 2000 and May 2001). The lowest values were obtained at the end of this season (Sept 2001, $184 \mu \mathrm{g} \mathrm{OM} \mathrm{g}^{-1} 15 \mathrm{~d}^{-1}$ ).

In relation to $\mathrm{SMBC}$, the highest levels were recorded in spring and autumn, and especially during the fallow period (Table 5). After May 2001, once the maximum SMBC was reached, an important decreased in this parameter was observed and remained during the following samplings. However, SMBC increased again in September 2002, especially in the organic fertilizer treatment, and in May 2003, coinciding with the end of the vetch crop.

The efficiency of soil microorganisms $\left(\mathrm{CO}_{2}\right.$ to ATP ratio) was higher in the cooler months during the vetch crop (Table 5, Figure 1), when the microbial biomass decreased and the soil organic matter mineralization (measured at laboratory) presented similar values than those reached in spring and autumn.

The average soil $\mathrm{NO}_{3}-\mathrm{N}$ content was significantly higher in inorganically $(17.3 \mathrm{ppm})$ than in organically $(14.1 \mathrm{ppm})$ or no-fertilized soils (15.0 ppm) (Table 5). However, despite the general results in relation to the averaged soil $\mathrm{NO}_{3}-\mathrm{N}$ contents, statistical differences among treatments were only observed in May 2002, probably as result of the low rainfall registered in the previous winter $(97.1 \mathrm{~mm})$ (Figure 1), which could limit the leaching of nitrates and therefore to improve the chemical fertilizer efficiency. $\mathrm{NO}_{3}-\mathrm{N}$ remained in low levels during fallow and reached the maximum values at the end of this period in the three fertilization treatments (34.8 ppm average, equivalent to $100 \mathrm{~kg} \mathrm{ha}^{-1}$ in the $0.20 \mathrm{~m}$ surface soil layer) (Table 5 ). In general, during the barley growing season, the soil $\mathrm{NO}_{3}-\mathrm{N}$ content was higher with chemical fertilization than in the other two treatments. In each case, soil $\mathrm{NO}_{3}-\mathrm{N}$ levels decreased as the crop cycle advanced as consequence of plant extractions.

\section{Discussion}

It is well documented that the treatments which supply more carbon to the system will generate a higher amount of soil organic matter and therefore a higher soil microbial biomass and microbial activity [2, 12, 23-25]. However, in this study the increase of the carbon supply did not result in an increase of the soil parameters measured (SOM, SOMM, SMBC, and $\mathrm{CO}_{2}$ to ATP ratio), being more affected by the specific meteorological conditions than for the type or amount of the fertilizers employed.

During the barley crop, soils did not receive external organic matter supplies from crop residues because this crop followed a fallow period, and only the organic treatment received the compost as organic supply. However, this external input of organic matter did not result in an increase of SOM. It could be explained by the dry winter which characterized that season (2001/2002), appropriate conditions for limiting the leaching of nitrates and getting a good efficiency of chemical fertilizers, and therefore for obtaining a great plant biomass production which could later be incorporated into the soil in the inorganic treatment, effect which was also observed for vetch crop. For this reason, the total biomass accumulated was higher in the chemical than in the other fertilization treatments, although the total inputs of organic matter to the soils were similar among them. Pardo et al. [26], however, did not find differences among chemical, organic and no-fertilizer treatments in cereal and vetch biomass in a similar approach.

In relation to SOMM, the highest values were reached in the first sampling (higher $\mathrm{CO}_{2}$ release rate) because at that date all crop residues from the previous wheat crop were still undecomposed (or only partially decomposed) as a result of the scarce rainfall registered in the previous summer $(2.0 \mathrm{~mm})$. Consequently, when the soil sample was placed at the laboratory under the appropriate temperature and humidity conditions for biological activity, the large amount of carbon contained in the sample produced a large $\mathrm{CO}_{2}$ release. Thus, SOMM at the laboratory was always higher at the end of summer provided that a source of organic matter was previously added, because in these cases the soil sample contained a certain amount of carbon which could be mineralised. During the fallow period, SOMM was high and practically constant, when crop residues 
TABLE 2: Aboveground vegetal biomass $\left(\mathrm{kg} \mathrm{ha}^{-1}\right)$ in the different crops over the period 1999-2003.

\begin{tabular}{lccccc}
\hline Treatment & $1999 / 2000$ & $2000 / 2001$ & $2001 / 2002$ & $2002 / 2003$ & Vetch $^{*}$ \\
& Wheat & Fallow & Barley & $3032 \mathrm{a}$ & Total accumulated $^{1}$ \\
\hline Chemical & $9313 \mathrm{a}$ & 0 & $14201 \mathrm{a}$ & $2406 \mathrm{~b}$ & $17233 \mathrm{a}$ \\
Organic & $9988 \mathrm{a}$ & 0 & $10419 \mathrm{~b}$ & $2098 \mathrm{~b}$ & $12825 \mathrm{~b}$ \\
No fertilization & $10073 \mathrm{a}$ & 0 & $12668 \mathrm{ab}$ & $14766 \mathrm{~b}$ \\
\hline Average & 9792 & 0 & 12429 & 2512 & 14941 \\
\hline
\end{tabular}

In italic the crop sequence considered in this study ( ${ }^{1}$ also for total accumulated data). Different small letters in the same column indicate significant differences at $P<0.05$.

TABLE 3: Total inputs of organic matter $\left(\mathrm{kg} \mathrm{ha}^{-1}\right)$ incorporated into the soil over the period 2000-2003.

\begin{tabular}{lcccc}
\hline Treatment & $2000 / 2001$ & $2001 / 2002$ & $2002 / 2003$ & Totch \\
Fallow & Barley & 0 & $10740 \mathrm{a}$ & $18789 \mathrm{a}$ \\
Chemical & $8049 \mathrm{a}$ & 2500 & $8024 \mathrm{~b}$ & $19316 \mathrm{a}$ \\
Organic & $8792 \mathrm{a}$ & 0 & $9358 \mathrm{ab}$ & $18625 \mathrm{a}$ \\
No fertilization & $9267 \mathrm{a}$ & 833 & 9374 & 18910 \\
\hline Average & 8703 & & \\
\hline
\end{tabular}

Different small letters in the same column indicate significant differences at $P<0.05$.

remained undecomposed in the soil and, however, under the appropriate conditions at the laboratory, the decomposition process began with the corresponding $\mathrm{CO}_{2}$ emission. The low SOMM measured at the end of the fallow period indicated that the mineralization process of the crop residues had already taken place.

SMBC was also affected by the weather conditions; thus, the highest levels were recorded in spring and autumn, when temperature and humidity conditions were suitable for the microorganisms to grow, and especially during the fallow period due to the presence of organic carbon from the previous wheat crop. This effect was also observed at the beginning of the vetch crop and especially in the organic fertilizer treatment (appropriate humidity and temperature conditions, and organic carbon from both the barley crop and the organic fertilization). However, the low temperatures reached in winter led to a low activity of soil microorganisms. In summer, high SMBC was only observed when it was rainy and there were crop residues rich in carbon. During the barley crop, the low SMBC values were probably as result of the lack of organic carbon from the previous fallow period and the low temperatures reached that season.

The analysis of the results obtained in this trial suggests that inputs of $2500 \mathrm{~kg} \mathrm{ha}^{-1}$ of compost (organic fertilization) did not lead to an improvement of the soil biochemical parameters. These results contrast with most studies developed in similar environments; thus, García-Galavís et al. [27] and Marinari et al. [24] indicated that soils organically fertilized usually had more active microbial populations than soils with chemical fertilization, which means an improvement in soil quality. However, most of these studies were performed with high amounts of compost, greater than $20 \mathrm{tha}^{-1}$, and often in irrigated crops, which even resulted in $\mathrm{NO}_{3}-\mathrm{N}$ plant levels higher than the maximum allowed [28].

Soil moisture is an important factor for microorganisms growing and plant residue decomposition [29]. When high soil moisture is present, then there is less oxygen available for microbial growing. In the same way, Calabria et al. [30] found the lowest SOMM rates under dryland conditions. In autumn and spring, inorganic $\mathrm{N}$ is immobilized (increase of SMBC), and once the carbon present in plant residues is consumed, microbial biomass decreases and nitrogen releases when moisture levels for nitrification are appropriate. In dry summers the nitrification process is limited, being reactivated during the following autumn, and decreases again in winter due to low temperatures. The results obtained by Farrus et al. [28] in different lettuce growing seasons under organic and no fertilizer treatments also support the effect of the meteorological conditions on soil chemical and biological parameters; thus, they did not find differences among treatments when lettuce grew in spring-summer because temperatures favored the organic matter mineralization process.

$\mathrm{NO}_{3}-\mathrm{N}$ remained in low levels during fallow either because it was still immobilized, forming organic compounds (not mineralized), or because it had become part of the microbial biomass. This parameter reached the highest values at the end of summer, with levels around $35 \mathrm{ppm}$ (equivalent to $100 \mathrm{~kg} \mathrm{Nha}^{-1}$ ) regardless of the fertilization treatment, enough amounts for rainfed cereal crops in semiarid environments $\left(2000 \mathrm{~kg} \mathrm{ha}^{-1}\right.$ grain yields) [3]. It explains why the cereal-fallow rotation has been historically used by farmers in rainfed crops, even before the appearance of external fertilizers.

Application of compost did not result in an increase of vegetal biomass and soil $\mathrm{NO}_{3}-\mathrm{N}$ content, which indicates that the organic nitrogen supplied by the compost $\left(70 \mathrm{~kg} \mathrm{ha}^{-1}\right)$ was not transformed into nitrate, in agreement with Pardo et al. [26]. Van Faassen and Van Dijk [31] also reported that mineralization of organic nitrogen from manures is rather variable depending on manure type and soil properties.

In general, SOM at the end of the study maintained their initial levels, in concordance with Pardo et al. [26], which indicates that crop rotations and burying the vetch 


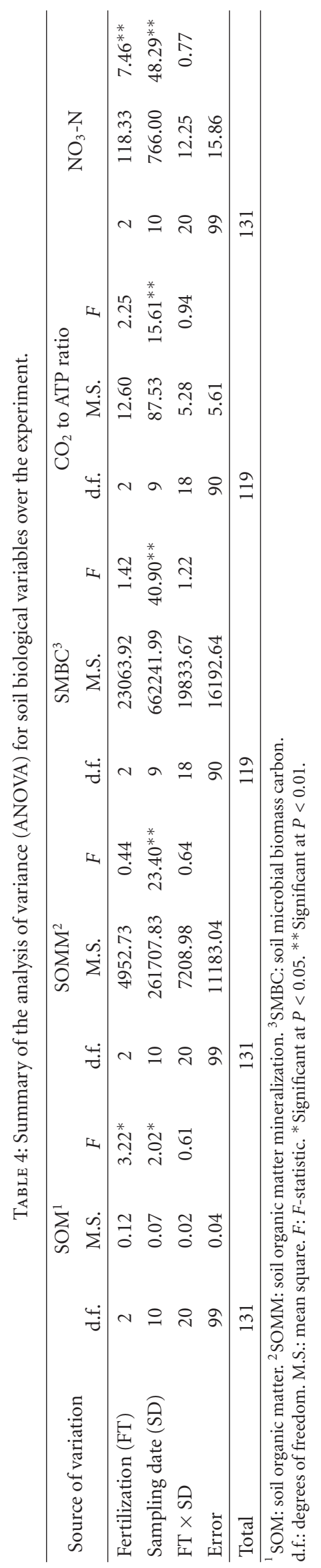




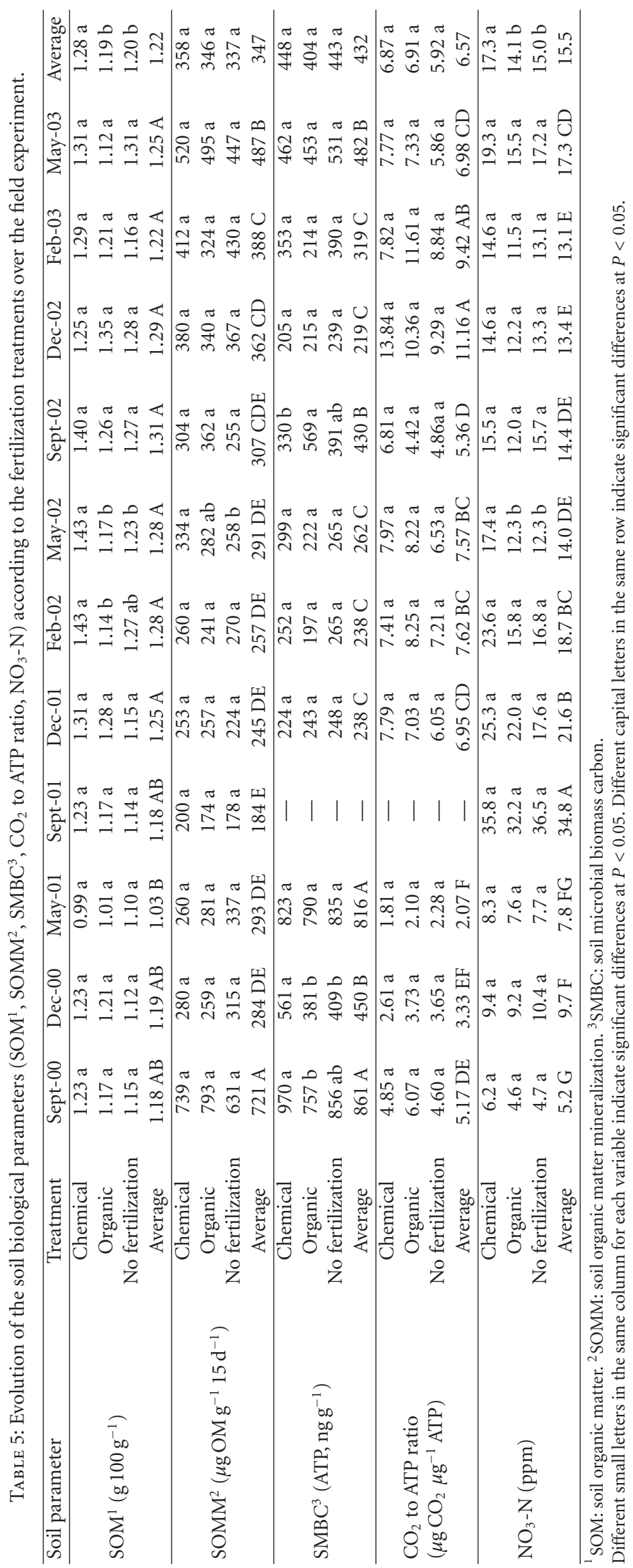


and the crop residues after harvesting help to maintain the soil fertility.

\section{Conclusions}

The study of different soil biochemical parameters in a rainfed crop-rotation in a sandy-loam soil indicates that the improvement of soil quality depended more on the weather conditions than on the type of fertilizers used. Organic fertilization consisting of $2500 \mathrm{~kg}$ compost ha $\mathrm{ha}^{-1}$ did not improve the quantity and quality of soil organic matter, being similar to those observed when chemical or no fertilizer were used. However, the inclusion of a legume in the cropping system and the burying of crop residues after harvesting were enough to maintain the initial soil organic matter levels. Including a fallow period in a crop rotation is advisable because the soil microorganism populations increased (appropriate moisture and temperature conditions and not competition with crops). Additionally, at the end of fallow soil $\mathrm{NO}_{3}-\mathrm{N}$ contents were high and enough for cereal growth in semiarid environments.

\section{Acknowledgments}

The research was supported by projects INIA SC 96-081 and RTA 01-108. The authors would like to thank Luis Martín de Eugenio and José Ramón Vadillo for performing the field operations and helping to compile the corresponding data over the study period.

\section{References}

[1] C. Tu, J. B. Ristaino, and S. Hu, "Soil microbial biomass and activity in organic tomato farming systems: effects of organic inputs and straw mulching," Soil Biology and Biochemistry, vol. 38, no. 2, pp. 247-255, 2006.

[2] A. S. F. Araújo, V. B. Santos, and R. T. R. Monteiro, "Responses of soil microbial biomass and activity for practices of organic and conventional farming systems in Piauí state, Brazil," European Journal of Soil Biology, vol. 44, no. 2, pp. 225-230, 2008.

[3] M. M. Moreno, C. Lacasta, R. Meco, and C. Moreno, "Rainfed crop energy balance of different farming systems and crop rotations in a semi-arid environment: results of a long-term trial," Soil and Tillage Research, vol. 114, no. 1, pp. 18-27, 2011.

[4] S. Melero, J. C. R. Porras, J. F. Herencia, and E. Madejon, "Chemical and biochemical properties in a silty loam soil under conventional and organic management," Soil and Tillage Research, vol. 90, no. 1-2, pp. 162-170, 2006.

[5] C. A. Helander and K. Delin, "Evaluation of farming systems according to valuation indices developed within a European network on integrated and ecological arable farming systems," European Journal of Agronomy, vol. 21, no. 1, pp. 53-67, 2004.

[6] U. Jørgensen, T. Dalgaard, and E. S. Kristensen, "Biomass energy in organic farming - the potential role of short rotation coppice," Biomass and Bioenergy, vol. 28, no. 2, pp. 237-248, 2005.

[7] IFOAM Norms, International Federation of Organic Agriculture Movements, 2002.
[8] A. Fließbach and P. Mäder, "Microbial biomass and sizedensity fractions differ between soils of organic and conventional agricultural systems," Soil Biology and Biochemistry, vol. 32, no. 6, pp. 757-768, 2000.

[9] J. C. García Gil, Efectos residuales y acumulativos producidos por la aplicación de compost de residuos urbanos y lodos de depuradoras sobre agrosistemas mediterráneos degradados, Ph.D. thesis, Science Faculty, Autonomous University of Madrid, Madrid, Spain, 2001.

[10] D. L. Karlen, M. J. Mausbach, J. W. Doran, R. G. Cline, R. F. Harris, and G. E. Schuman, "Soil quality: a concept, definition, and framework for evaluation," Soil Science Society of America Journal, vol. 61, no. 1, pp. 4-10, 1997.

[11] J. W. Doran, M. Sarrantonio, and M. A. Liebig, "Soil health and sustainability," in Advances in Agronomy, D. L. Sparks, Ed., vol. 56, pp. 25-37, Academic Press, San Diego, Calif, USA, 1996.

[12] S. Melero, E. Madejón, J. C. Ruiz, and J. F. Herencia, "Chemical and biochemical properties of a clay soil under dryland agriculture system as affected by organic fertilization," European Journal of Agronomy, vol. 26, no. 3, pp. 327-334, 2007.

[13] M. R. Carter, E. G. Gregorich, D. W. Anderson, J. W. Doran, H. H. Janzen, and F. J. Pierce, "Chapter 1 Concepts of soil quality and their significance," Developments in Soil Science, vol. 25, pp. 1-19, 1997.

[14] E. E. Marriott and M. Wander, "Qualitative and quantitative differences in particulate organic matter fractions in organic and conventional farming systems," Soil Biology and Biochemistry, vol. 38, no. 7, pp. 1527-1536, 2006.

[15] D. Rotenberg, A. J. Wells, E. J. Chapman, A. E. Whitfield, R. M. Goodman, and L. R. Cooperband, "Soil properties associated with organic matter-mediated suppression of bean root rot in field soil amended with fresh and composted paper mill residuals," Soil Biology and Biochemistry, vol. 39, no. 11, pp. 2936-2948, 2007.

[16] A. P. Silva, L. C. Babujia, J. C. Franchini, R. A. Souza, and M. Hungria, "Microbial biomass under various soil- and cropmanagement systems in short- and long-term experiments in Brazil," Field Crops Research, vol. 119, no. 1, pp. 20-26, 2010.

[17] M. Fernández-Pascual, M. de María, and M. R. de Felipe, "Fijación biológica de nitrógeno: factores limitantes," in Ciencia y Medio Ambiente, F. Valladares, Ed., pp. 195-202, CSIC, Madrid, Spain, 2002.

[18] USDA, Keys to Soil Taxonomy, Tenth Edition, Soil Survey Staff, United States Department of Agriculture NRCS, 2006.

[19] J. H. Wetters and K. L. Uglum, "Direct spectrophotometric simultaneous determination of nitrite and nitrate in the ultraviolet," Analytical Chemistry, vol. 42, no. 3, pp. 335-340, 1970.

[20] N. Maire, D. Borcard, E. Laczkó, and W. Matthey, “Organic matter cycling in grassland soils of the Swiss Jura mountains: biodiversity and strategies of the living communities," Soil Biology and Biochemistry, vol. 31, no. 9, pp. 1281-1293, 1999.

[21] D. A. Wardle and A. Ghani, "A critique of the microbial metabolic quotient $\left(q \mathrm{CO}_{2}\right)$ as a bioindicator of disturbance and ecosystem development," Soil Biology and Biochemistry, vol. 27, no. 12, pp. 1601-1610, 1995.

[22] T. H. Anderson and K. H. Domsch, "Application of ecophysiological quotients $\left(q \mathrm{CO}_{2}\right.$ and $\left.\mathrm{qD}\right)$ on microbial biomasses from soils of different cropping histories," Soil Biology and Biochemistry, vol. 22, no. 2, pp. 251-255, 1990.

[23] E. Madejón, R. López, J. M. Murillo, and F. Cabrera, "Agricultural use of three (sugar-beet) vinasse composts: effect 
on crops and chemical properties of a Cambisol soil in the Guadalquivir river valley (SW Spain)," Agriculture, Ecosystems and Environment, vol. 84, no. 1, pp. 55-65, 2001.

[24] S. Marinari, G. Masciandaro, B. Ceccanti, and S. Grego, "Evolution of soil organic matter changes using pyrolysis and metabolic indices: a comparison between organic and mineral fertilization," Bioresource Technology, vol. 98, no. 13, pp. 24952502, 2007.

[25] Q. R. Wang, Y. C. Li, and W. Klassen, "Changes of soil microbial biomass carbon and nitrogen with cover crops and irrigation in a tomato field," Journal of Plant Nutrition, vol. 30, no. 4, pp. 623-639, 2007.

[26] G. Pardo, J. Cavero, J. Aibar, and C. Zaragoza, "Nutrient evolution in soil and cereal yield under different fertilization type in dryland," Nutrient Cycling in Agroecosystems, vol. 84, no. 3, pp. 267-279, 2009.

[27] P. A. García-Galavís, C. Santamaría, J. C. Ruiz, and A. Daza, "Efecto beneficioso de la agricultura ecológica sobre los microorganismos del suelo," in Agroecología: Referente Para la Transición de los Sistemas Agrarios, VI SEAE Congress, pp. 1143-1151, Madrid, Spain, 2004.

[28] E. Farrus, M. Adrover, A. Forss, and J. Vadell, "Comparación de tres fuentes de materia orgánica sobre las características del suelo," in Agroecología: Referente Para la Transición de los Sistemas Agrarios, VI SEAE Congress, pp. 1111-1123, Madrid, Spain, 2004.

[29] Z. Huang, Z. Xu, and C. Chen, "Effect of mulching on labile soil organic matter pools, microbial community functional diversity and nitrogen transformations in two hardwood plantations of subtropical Australia," Applied Soil Ecology, vol. 40, no. 2, pp. 229-239, 2008.

[30] C. Calabria, I. Bautista, and M. Valero, "Índices biológicos de disponibilidad de nitrógeno en suelos de la Comunidad Valenciana," in Agroecología: Referente para la Transición de los Sistemas Agrarios, VI SEAE Congress, pp. 1017-1032, Madrid, Spain, 2004.

[31] H. G. Van Faassen and H. Van Dijk, "Manure as a source of nitrogen and phosphorus in soils," in Animal Manure on Grassland and Fodder Crops, Fertilizer or Waste Development in Plant and Soil Sciences, H. G. van der Meer, R. J. Unwen, T. A. van Dijk, and G. C. Ennik, Eds., pp. 27-45, Martinus Nijhoff Publishers, Dordrecht, The Netherlands, 1987. 

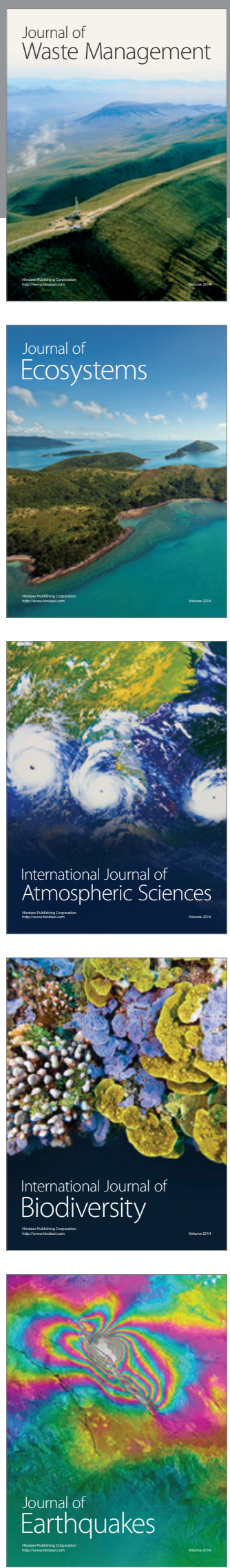
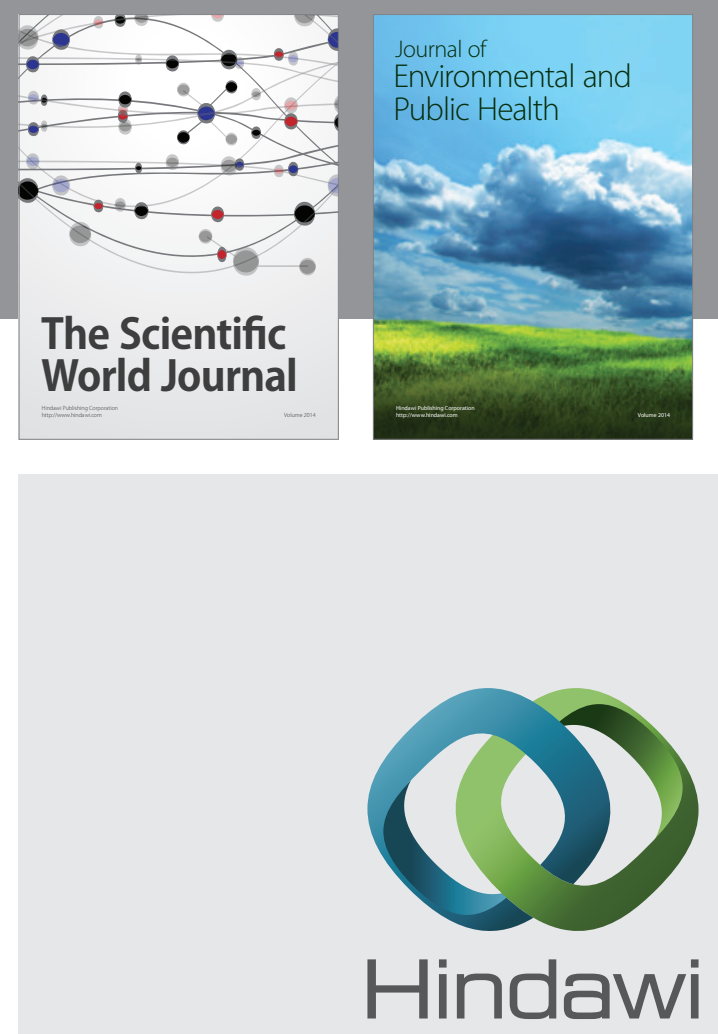

Submit your manuscripts at

http://www.hindawi.com
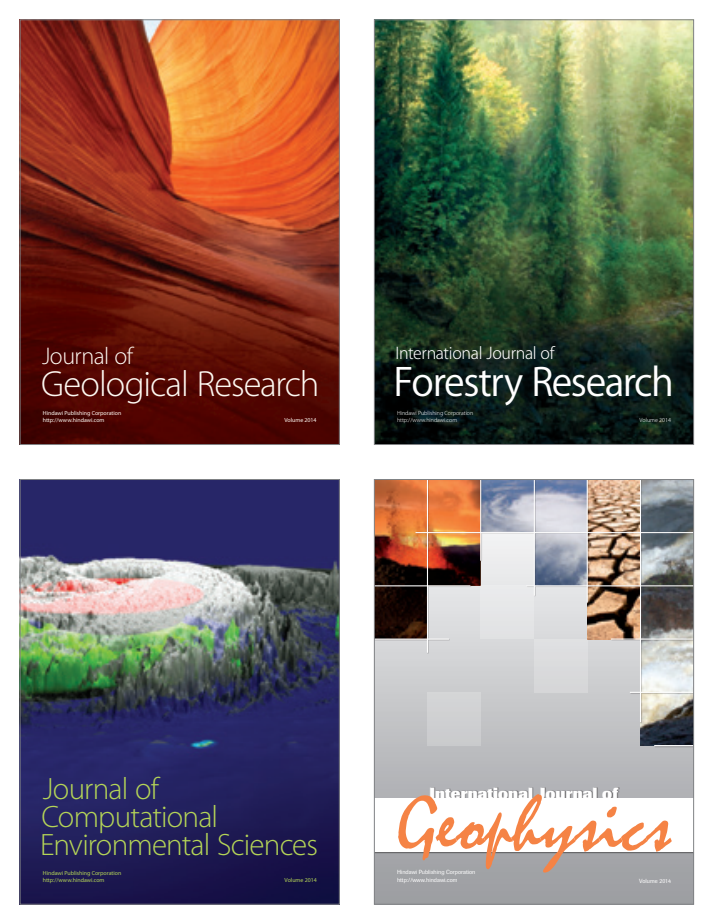
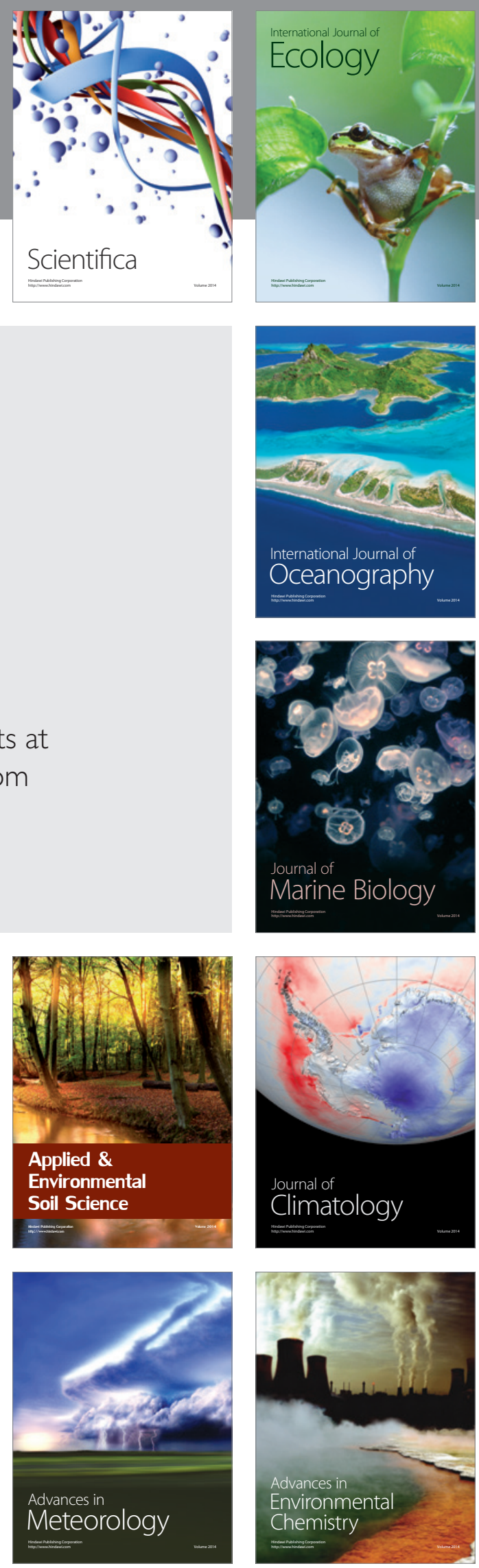